\title{
Barriers to Informal Caregiving of Persons Living with Dementia in Barbados: A Phenomenological Inquiry
}

\author{
CR Brown ${ }^{1}$, MM Murphy ${ }^{2}$
}

\begin{abstract}
Objective: To explore the barriers of primary informal caregivers to caring for persons living with dementia (PLWDs) in Barbados.

Methods: A qualitative, phenomenological methodology was adopted. Eight in-depth, semistructured interviews were conducted with primary informal caregivers of PLWDs. Transcripts were analysed according to Giorgi's four-step phenomenological framework.

Results: Four themes emerged: imbalanced family dynamics, financial and time constraints, dissatisfaction with formal care services, and misunderstanding of complex symptomatology. Conclusion: Understanding the lived experiences of informal caregiving highlighted the specific barriers to providing optimal care for PLWDs in Barbados. The 'Strategy and Plan of Action on Dementias in Older Persons (2015-2019)' by the Pan American Health Organization and the World Health Organization guides the support for caregivers, and this study provides context-based evidence to pursue effective approaches. Results are critical to the appropriate design of contextually appropriate training and services in support of informal caregiving.
\end{abstract}

Keywords: Ageing, Alzheimer's disease, dementia, elderly, qualitative

\section{Barreras al cuidado informal de personas con demencia en Barbados: una investigación fenomenológica}

\author{
CR Brown ${ }^{1}$, MM Murphy²
}

\begin{abstract}
RESUMEN
Objetivo: Explorar las barreras que los cuidadores primarios informales enfrentan al cuidar personas con demencia (PCD) en Barbados.

Métodos: Se adoptó una metodología cualitativa y fenomenológica. Se realizaron ocho entrevistas en profundidad, semiestructuradas, a cuidadores primarios informales de PCD. Las transcripciones fueron analizadas según el marco fenomenológico de cuatro pasos de Giorgi. Resultados: Surgieron cuatro temas: la dinámica familiar desequilibrada, las limitaciones de tiempo y finanzas, la insatisfacción con los servicios de atención formal, y la interpretación errónea de la sintomatología compleja.

Conclusión: La comprensión de las experiencias vividas por los cuidadores informales fue clave en la detección de las barreras especificas que estos enfrentaban a la hora de brindar una atención óptima a PCD en Barbados. La 'estrategia y plan de acción sobre las demencias
\end{abstract}

From: ${ }^{1}$ George Alleyne Chronic Disease Research Centre, Bridgetown, Barbados, West Indies and ${ }^{2}$ Faculty of Medical Sciences, The University of the West Indies, Cave Hill, Barbados, West Indies.
Correspondence: Ms CR Brown, George Alleyne Chronic Disease Research Centre, Jemmot's Lane, Bridgetown, Barbados, West Indies. Email: catherine.brown@cavehill.uwi.edu 
en las personas de edad (2015-2019)' por la Organización Panamericana de la salud y la Organización Mundial de la Salud, sirve de guía al apoyo que ofrecen los cuidadores, y este estudio proporciona pruebas contextuales para buscar enfoques efectivos. Los resultados son fundamentales para diseñar de manera adecuada tanto el entrenamiento como los servicios contextualmente apropiados en apoyo al cuidado informal.

Palabras clave: Envejecimiento, enfermedad de Alzheimer, demencia, anciano, cualitativo

West Indian Med J 2018; 67 (3): 207

\section{INTRODUCTION}

The 'Strategy and Plan of Action on Dementias in Older Persons (2015-2019)' by the Pan American Health Organization and the World Health Organization (WHO) (Plan of Action) recognizes threats imposed by projected changes in age profiles across the Caribbean (1). Among other Caribbean territories, Barbados is expected to experience the highest increase in the proportion of population aged $>60$ years and $>80$ years by 2050 , reaching $35.4 \%$ and $9.6 \%$ respectively (2). Provisions have been made on a policy level to accommodate this demographic shift, including the adoption of the Caribbean Charter on Health and Ageing (1999), Madrid Action Plan on Ageing (1999) and the National Policy on Ageing in Barbados (2012) (3-5). Yet, there exists a paucity of dementia-related research in Barbados and the Caribbean at large, with only Cuba, the Dominican Republic, Puerto Rico and Jamaica offering epidemiological data (6).

Global costs of dementia were reported in 2015 to be over US\$800 billion, and informal care was cited as the greatest contributor (6). Given the complexity and differentiation of health service organization and its dependency on contextual realities, effective and sustainable programming must occur with an understanding of the lived experiences within each setting (7). Barbados lacks an evidence base required for culturally adapted programming and policy. In keeping with WHO's recommendations, this study explored the barriers that informal caregivers in Barbados face with persons living with dementia (PLWDs) and aimed to provide a first step towards the local implementation of the Plan of Action (1).

\section{SUBJECTS AND METHODS}

A phenomenological approach was used to study caregiving of PLWDs, which assumes all phenomena to be subject to the act of perception and studies experiences as they are subjectively lived and understood (8).
The sample consisted of adult primary informal caregivers of PLWDs. Recruitment was conducted by two physicians via purposive sampling of their private and public patient databases. The physicians made initial contact with each primary caregiver via telephone to explain details of the study and determine their interest in participation. Researchers made direct contact with interested caregivers via telephone to arrange an interview. No data existed on the number of PLWDs receiving informal care at home in Barbados. Yet, the number was likely to be small given that the $>60$-yearold population was approximately 56000 ; therefore, a sample size of eight persons was likely sufficient to reach saturation (9).

In-depth, one-on-one, semi-structured interviews were conducted at the caregivers' homes. Interviews lasted 45-65 minutes, based on a semi-structured interview guide which enquired on their daily care routine, guiding principles, satisfaction of care, and difficult situations. They were audio-recorded and transcribed verbatim into ATLAS.ti v 7 qualitative data analysis software. Data were analysed according to Giorgi's four-step method of phenomenological analysis: capturing the sense of the whole, determining the participant's natural meaning units, transforming meaning units into central themes, and finally condensing central themes into essential, non-redundant revelatory themes (10).

The study was approved by the International Review Board at The University of the West Indies, Cave Hill, Barbados, and Barbados' Ministry of Health. Participants' written informed consent was obtained.

\section{RESULTS}

The Table describes the demographics of the eight caregivers. All participants were Afro-Caribbean Barbadians, except for Lauren, an Afro-Caribbean Guyanese.

Four central themes were extracted from the interview data: imbalanced family dynamics, financial and 
Table: Demographics of the caregivers

\begin{tabular}{|c|c|c|c|c|c|c|}
\hline \multicolumn{5}{|c|}{ Caregiver* } & \multicolumn{2}{|c|}{$\begin{array}{l}\text { Persons living with } \\
\text { dementia (PLWDs) }\end{array}$} \\
\hline Number & $\begin{array}{l}\text { Name**, } \\
\text { age (years) }\end{array}$ & $\begin{array}{l}\text { Relation to } \\
\text { PLWDs }\end{array}$ & $\begin{array}{c}\text { Education } \\
\text { level }\end{array}$ & Occupation & $\begin{array}{l}\text { Name**, } \\
\text { age (years) }\end{array}$ & $\begin{array}{c}\text { Time since } \\
\text { diagnosis }\end{array}$ \\
\hline 1 & Sonia, 72 & Wife & Secondary & Housewife & John, 78 & 2 years \\
\hline 2 & Thelma, 73 & Wife & $\begin{array}{l}\text { Tertiary } \\
\text { (English) }\end{array}$ & $\begin{array}{l}\text { Retired matron of an } \\
\text { orphanage }\end{array}$ & Victor, 93 & 6 years \\
\hline 3 & Sandra, 58 & Daughter & Secondary & School warden & Lilius, 99 & 10 years \\
\hline 4 & Miriam, 68 & Wife & Secondary & $\begin{array}{l}\text { Part-time } \\
\text { housekeeper }\end{array}$ & Herbert, 84 & 7 years \\
\hline 5 & Sherry, 54 & Daughter & $\begin{array}{l}\text { Tertiary } \\
\text { (accounting) }\end{array}$ & Office worker & Nora, 74 & 2 years \\
\hline 6 & Lynette, 60 & Niece & $\begin{array}{l}\text { Tertiary } \\
\text { (nursing) }\end{array}$ & $\begin{array}{l}\text { Retired chef and } \\
\text { auxiliary nurse }\end{array}$ & Betty, 94 & 5 years \\
\hline 7 & Joanne, 49 & Daughter & $\begin{array}{l}\text { Tertiary } \\
\text { (information } \\
\text { technology) }\end{array}$ & $\begin{array}{l}\text { Retired data man- } \\
\text { ager of a gambling } \\
\text { firm }\end{array}$ & Tracy, 78 & 1.5 years \\
\hline 8 & Lauren, 53 & Wife & Secondary & $\begin{array}{l}\text { Private nurse for } \\
\text { elderly PLWDs }\end{array}$ & Douglas, 66 & 8 years \\
\hline
\end{tabular}

* Caregivers 1-5 had been caregiving for the PLWDs since the time of diagnosis of the PLWDs. Caregivers 6-8 had been caregivers of the PLWDs for four years, seven months and seven years respectively. ** All names are pseudonyms.

time constraints, dissatisfaction with formal care services, and misunderstanding of complex symptomatology.

\section{Imbalanced family dynamics}

While family and community support could assist caregiving efforts, the lack of family support was a source of hindrance. For instance, Joanne shared her frustrations in coping with her 'family situation' where her siblings and other family members had relinquished their support for her mother. Additionally, even family members who had not given up their responsibility strained care-giving efforts. Sherry explained her 'frustrating moments' in sharing the responsibility of caregiving with her young adult children whom she believed did not understand how to manage this role. She struggled to juggle the responsibilities of parenthood and attending to her children's needs with the responsibility of caring for her mother. While she admitted to herself that 'you can't think about your mum alone and don't think about [my children's wants]', she also recognized that 'they are young adults, not children anymore. So they need to step up'. Likewise, Sonia described the strained relationship between her son and her husband who were 'always at each other'. Lynette represented a key example of how family issues dictated her caregiving experience. She rationalized that 'everybody is not, um, patient, unless you know or are trained with a person with dementia' when she discussed how she assumed the caregiver role of her aunt when her cousins could not handle the responsibility of their mother.

\section{Financial and time constraints}

Caregivers, whether employed or unemployed, admitted to not offering as much care as they would like. Sherry was disappointed that she was unable to attend lectures on dementia due to her busy work schedule. Lynette, who was unemployed, divulged of not having enough time to take her aunt for walks: 'I KNOW that she don't get enough [exercise], yes. Because I'm so busy.'

Financial constraint was another major barrier. Lynette reported the insufficient money given by her family to care for her aunt, while Miriam stressed her struggles to get by solely with her ill husband's pension checks. As Sandra explained:

Money! Cus if we had money, we'd be able to get somebody to come in. You could pay somebody, or transportation, or...take her to a daycare. Those are things I talking about, yuh understand? But [pause], can't afford it.

All participants who worked full-time stated that money was the single barrier preventing them from offering the full-time care they desired for their loved ones. Yet, regardless of these financial struggles, Lynette elucidated the futility in putting a price on caregiving: 'there is no money that can...it's like priceless... [paying] for proper care'. 


\section{Dissatisfaction with formal care services}

Caregivers were concerned about overpopulation, and subsequent insufficiency and overmedication in formal care centres. Lauren, whose husband attended daycare several days a week so she could hold a job, admitted that her husband always came home 'very confused' and subsequently ordered the centre to withhold medication unless absolutely necessary. Some feared for potential abuse. Sonia lamented:

If you got three or four people [with dementia], how you could cope? And sometimes the people don't get treat good! They tie them there and pull them there... but when the family come and look for them, they all smiling and good.

In addition to this distrust, Miriam explained her worry that institutionalization would 'break their [loved ones'] heart'. In spite of the general hesitancy, some stressed on the lack of availability of formal care institutions. Sandra was frustrated with the inaccessibility as 'apparently, when you apply to get them in a home, you gotta wait like a year or more'. Thelma agreed on this need for more homes, while at the same time maintaining her reservations about their service: 'you would be bothered, you would still be worrying. It's a two-fold thing'. Overall, concerns of formal care institutions were cemented in the unanimous opinion that home care was the best care as 'in an institution they [don't] know anybody... So, to improve their lives...family around them makes a difference'.

\section{Misunderstanding of complex symptomatology}

Only after diagnosis did the caregivers learn of the slow, insidious development of dementia. Miriam explained coming close to leaving her husband during the prediagnosis period, admitting to constant fights. Even post-diagnosis, the caregivers attributed behavioural changes associated with dementia to the PLWD's personality: 'that is what causes some of the problems, cus we don't understand what is happening... you just put it all as that, that they are miserable and wicked. So then you don't treat them nice'. The caregivers also attributed behavioural change to other illnesses or life events. Sherry considered dehydration or grief as potential causes of her mother's confused state. In the midst of these presumptions, their efforts to help could be detrimental. For example, Sherry reported sending her mother on a trip to reconnect with overseas family members before the disease progressed. However, this trip proved unfavourable as she did not recognize many family members, and after which Sherry recognized having 'creat[ed] a spike' in disease progression, having returned home more disoriented. There was also difficulty in managing and planning care due to the overwhelming unpredictability of the disease course. Joanne explained:

I still view it like a lot of people. You're just getting old. But the fact that it encroaches on their everyday life so profoundly...this is what makes it so scary... then I think about you know, what happens when the day comes that she can't do everything? And I have to start dressing her? And how is she going to like that?

\section{DISCUSSION}

This is the first published study to explore lived experiences of caregivers to elucidate context-specific barriers to managing dementia in Caribbean homes. Caregiver experiences are essential for informing on the WHO's recommendation for a 'quality long-term care system that addresses the needs of dependent persons, their families, and caregivers' (1). Barriers included coping with family dynamics, managing financial and time constraints, dissatisfaction with formal care services, and misunderstanding of symptomatology. These findings are critical to appropriately create and enhance support services for informal caregivers.

It is important to interpret these findings within the context of its setting. The history of mental health in the Caribbean began with asylums constructed to sequester the mentally ill $(11,12)$. While other settings have since decentralized care to the community, many regional mental health services continue to exist centrally (12). Recently, there has been a transition where PLWDs are treated on the medical ward of general hospitals, as a 'secondary level' of community mental health (11). This model of care differs from international settings due to particular features of Barbados: limited financial and human resources directed towards elderly care and mental health in spite of pronouncements of numerous charters, plans and legislation in such areas $(5,12,13)$.

Our findings are supported by international research, indicating consistent struggles across different contexts (14-16). As evidenced, resilience of the family unit is crucial to offering optimal care, as family issues do not only impact the caregivers' burden, but also impose emotional distress and suboptimal care for PLWDs (15). Functional coping strategies are important to reduce caregiver anxiety and improve care offered (17). They also aid in addressing Objective 3.2 of the Plan of Action to 'create multisectoral care and training programs 
for informal and formal caregivers' (1). Furthermore, Objective 3.1 (to 'establish integrated, community-based networks... with family participation') (1) is particularly valuable in small island settings such as Barbados.

Insufficient time and finances are significant social barriers impeding the caregiving experience. The economic burden of dementia is already enormous, and increasing costs are expected to shift to the formal sector, holding serious implications for supporting informal caregivers and financing future care institutions (18). Yet, dissatisfaction with formal care is a crux to this expansion. Establishment of legal/regulatory frameworks based on international standards is recommended to guarantee quality care and protection of rights of PLWDs in formal care institutions (1) and to initiate a change in public perception. However, given Barbados' current economic limitations, more time-flexible jobs should be considered to assist primary caregivers so they can earn a salary to support their home care. In fact, caregivers are shown to benefit from outside work through its financial incentives, social interaction, and personal evaluation outside of the caregiver role (16). Finally, understanding the complexities of the symptomatology of dementia is a crucial element to caregiving. Given the variable course of dementia, this barrier is anticipated and can be addressed by health professionals creating a more informed patient cohort, through stronger support groups or hotlines, home-help services, and specialized training programmes (19).

The sample was heterogeneous in socio-economic standing and time spent caregiving, offering a range of standpoints. Yet, an all-female sample is important for interpretation as females perceive the caregiving experience differently from males, offering more time caring and more attention to personal care over task-oriented care (20). Limitations to data quantity and quality include the stigma associated with dementia which may hinder full disclosure of sensitive beliefs or behaviours. Also, self-reflexivity or a priori assumptions of the researcher can largely influence the directionality of interviews and interpretation of results $(21,22)$. While introspection and bracketing were conducted, their potential futility is acknowledged since bias is never entirely avoidable $(23,24)$.

\section{CONCLUSION}

This Barbados study offers a benchmark for other Caribbean settings in highlighting the importance of quality in the context of caregiving for PLWDs, such that recommended multisectoral care and training programmes are aligned to facilitate the specific needs of caregivers. To complement, quantitative studies are needed to capture the true burden of dementia and informal caregiving, along with qualitative work focussing on attitudes towards these areas.

\section{ACKNOWLEDGEMENTS}

The authors express gratitude to Dr Ramsay and Dr Belle for their commitment during recruitment and to Dr Trepel for his support in crafting this paper. This research received no grant from any funding agency. The authors declare that there was no potential conflict of interest.

\section{REFERENCES}

1. Pan American Health Organization and World Health Organization. Strategy and plan of action on dementias in older persons [Internet]. Washington, DC: World Health Organization; 2015 Sep [cited 2016 Jun 14]. Report No: CD54/8, Rev 1. Available from: http:// iris.paho.org/xmlui/bitstream/handle/123456789/28348/CD54-8-e. pdf? sequence $=1$ \&isAllowed $=\mathrm{y}$.

2. Economic Commission for Latin America and the Caribbean. Population ageing in the Caribbean: an inventory of policies, programmes, and future challenges [Internet]. Economic Commission for Latin America and the Caribbean; 2004 May [cited 2016 Jun 14]: 1-53. Report No: LC/CAR/G.772/Corr.1. Available from: www.cepal.org/en/ publications/38861-population-ageing-caribbean-inventory-policiesprogrammes-and-future-challenges.

3. Caribbean Community. Caribbean Charter on health and ageing launched [Internet]. CARICOM. 1999 [cited 2016 Jun 14]. Available from: http://caricom.org/media-center/communications/press-releases/ caribbean-charter-on-health-and-ageing-launched.

4. World Health Organization. Mental health system in Barbados [Internet]. Barbados; 2012 [cited 2017 May 5]. Available from: www.who.int/ mental_health/barbados_who_aims_report.pdf?ua $=1$.

5. National policy on ageing for Barbados: towards a society for all ages. Barbados: Barbados Ministry of Health; 2012 Jan.

6. Prince M, Wimo A, Guerchet M, Ali G-C, Wu Y-T, Prina M. World Alzheimer report 2015, the global impact of dementia [Internet]. London: Alzheimer's Disease International; 2015 [cited 2017 Jan 8]. Available from: www.alz.co.uk/research/WorldAlzheimerReport2015. pdf.

7. Godfrey M. Qualitative research in age and ageing: enhancing understanding of ageing, health and illness. Age Ageing 2015; 44: 726-7.

8. Daniels V. Lecture on phenomenology [Internet]. Sonoma State University. 2005 [cited 2016 Jun 6]. Available from: www.sonoma.edu/ users/d/daniels/phenomlect.html.

9. United Nations, Department of Economic and Social Affairs, Population Division. Data query [Internet]. United Nations, Department of Economic and Social Affairs. 2015 [cited 2017 May 5]. Available from: http://esa.un.org/unpd/wpp/DataQuery.

10. Whiting LS. Analysis of phenomenological data: personal reflections on Giorgi's method. Nurse Res 2002; 9: 60-74.

11. Abel WD, Kestel D, Eldemire-Shearer D, Sewell C, Whitehorne-Smith P. Mental health policy and service system development in the Englishspeaking Caribbean. West Indian Med J 2012; 61: 475-82.

12. World Health Organization. Mental health systems in the Caribbean region [Internet]. World Health Organization; 2011 [cited 2017 Jun 4]. Available from: www.who.int/mental_health/evidence/ mh_systems_caribbeans_en.pdf.

13. Springer CA. Barbados national report on aging (2007-2011) [Internet]. Barbados: Ministry of Health; 2012 [cited 2017 Jun 4]. Available from: www.cepal.org/celade/noticias/paginas/9/46849/barbados.pdf. 
14. Liu Y, Insel KC, Reed PG, Crist JD. Family caregiving of older Chinese people with dementia: testing a model. Nurs Res 2012; 61: 39-50.

15. World Health Organization, Alzheimer's Disease International. Supporting informal caregivers of people living with dementia [Internet]. Geneva: World Health Organization; 2012 [cited 2016 Jun 6]. Report No: WHO/MSD/MER/15.6. Available from: www.who.int/ mental_health/neurology/dementia/dementia_thematicbrief_informal_ care.pdf.

16. Dupuis S, Smale B, Epp T. Caregivers of persons with dementia: roles, experiences, support, and coping [Internet]. Ontario, Canada: University of Waterloo; 2004 [cited 2014 Aug 12]: 112. (Ontario Dementia Caregiver Needs Project.) Available from: https://uwaterloo.ca/murray-alzheimer-research-and-education-program/sites/ ca.murray-alzheimer-research-and-education-program/files/uploads/ files/InTheirOwnVoices-LiteratureReview.pdf.

17. Iavarone A, Ziello AR, Pastore F, Fasanaro AM, Poderico C. Caregiver burden and coping strategies in caregivers of patients with Alzheimer's disease. Neuropsychiatr Dis Treat 2014; 10: 1407-13.
18. Wimo A, Jönsson L, Bond J, Prince M, Winblad B. The worldwide economic impact of dementia 2010. Alzheimers Dement 2013; 9: 1-11.

19. Chien L-Y, Chu H, Guo J-L, Liao Y-M, Chang L-I, Chen C-H et al. Caregiver support groups in patients with dementia: a meta-analysis. Int J Geriatr Psychiatry 2011; 26: 1089-98.

20. Navaie-Waliser M, Spriggs A, Feldman P. Informal caregiving: differential experiences by gender. Med Care 2002; 40: 1249-59.

21. Green J, Thorogood N. Qualitative research methods for health research. $2^{\text {nd }}$ ed. London: Sage Publications; 2009.

22. Dicicco-Bloom B, Crabtree BF. The qualitative research interview. Med Educ 2006; 40: 314-21.

23. De Castro A. Introduction to Giorgi's existential phenomenological research method. Psicol Desde El Caribe 2003; 11: 45-56.

24. Patton MQ. Qualitative research and evaluation methods. $3^{\text {rd }}$ ed. California: Sage Publications; 2002. 